\title{
Sheared peridotites from Kimberley \\ (South Africa): Ti-enrichment of \\ olivine neoblasts through a $1200^{\circ} \mathrm{C}$ hot metasomatic agent
}

\author{
CATHARINA HECKEL ${ }^{1}$, ALAN B. WOODLAND ${ }^{2}$, JOLIEN \\ LINCKENS $^{1}$ AND SALLY A. GIBSON ${ }^{3}$ \\ ${ }^{1}$ Goethe-University Frankfurt \\ ${ }^{2}$ Goethe University of Frankfurt \\ ${ }^{3}$ University of Cambridge \\ Presenting Author: c.heckel@em.uni-frankfurt.de
}

Sheared peridotites are the direct result of strong deformation in the deeper portions of the cratonic mantle lithosphere. Such rocks provide important insights into how such processes operate, not only in terms of deformation style, but also whether there is a link between deformation and metasomatism. We have investigated 14 sheared peridotites xenoliths from the Kimberley diamond mine group (South Africa) with microstructures ranging from porphyroclastic to fluidal mosaic [1]. Ten of these are garnet-peridotites $\left(\mathrm{X}_{\mathrm{Fo}}=92-94\right)$, including one harzburgite. Three others are phlogopite-bearing $\left(X_{\mathrm{Fo}}=91-93\right)$ with minor (to major) amounts of spinel and 1 sample is a dunite $\left(\mathrm{X}_{\mathrm{Fo}}=88\right)$. Here we focus on olivine trace element measurements by EPMA, which allow analysis as a function of grain size, particularly of fine-grained neoblasts down to $10 \mu \mathrm{m}$ in size or smaller.

Temperatures and pressures, estimated with several geothermobarometers, indicate equilibration conditions at $\sim 40 \mathrm{kbar}$ and $840-1000^{\circ} \mathrm{C}$ for the whole sample suite. Trace element analysis of olivine neoblasts allowed application of the Al-in-olivine [2] and Cr-in-olivine [3] thermometers. Results indicate a strong increase in temperature up to $1200^{\circ} \mathrm{C}$ at $40 \mathrm{kbar}$, with this increase generally correlating with an increase in $\mathrm{Ti}$ content (up to $300 \mathrm{ppm}$ ) in the olivine neoblasts. This correlation is not exhibited by the phlogopite-bearing peridotites, since $\mathrm{Ti}$ contents are apparently buffered by this phase.

Combined with olivine crystallographic preferred orientations (CPOs) determined by electron backscatter diffraction (EBSD) measurements, we can show that a water-rich (B, C, E type CPO [4]) metasomatic agent, probably melt (AG-type or "a-c-switch" CPO [5]), was present at the time of deformation and olivine recrystallisation. Preliminary analysis suggests the agent was protokimberlitic [6].

[1] Boullier \& Nicolas (1975), Physics and Chemistry of the Earth 9, 467-468, 468a, 469-475. [2] Bussweiler et al. (2017), Lithos 272-273, 301-314. [3] deHoog et al. (2010), Chemical Geology 270, 196-215. [4] Jung (2017), Geosciences Journal 21, 985-1011. [5] Qi et al. (2018) Geochemistry, Geophysics, Geosystems 19, 316-336. [6] Giuliani et al. (2016), Lithos 240243, 189-201. 